\title{
LOS ESTUDIOS CON ANIMALES. ÉTICA PARA SITUACIONES DIVERSAS
}

Con este número de Acta Bioethica deseamos aportar algunas pautas de interpretación para el análisis ético de un rasgo fundamental de la ciencia en los países occidentales: su carácter experimental.

"Carácter experimental” sugiere que la fuente de pruebas y evidencias se sitúa en la sensorialidad de quien interroga a la Naturaleza. Tal es la interpretación histórica habitual cuando se contrasta la ciencia medieval con la renacentista. Andrea Vesalio, por ejemplo, suele presentarse como innovador por introducir la mirada propia en el cadáver humano (auténtica "autopsia") frente a las especulaciones galénicas basadas en extrapolar la anatomía de otros animales.

La noción de "experimento" de la Edad Moderna no es la vieja noción de "experiencia" con que el observador de la Naturaleza aceptaba su mensaje. Según Paracelso, por ejemplo, ser sujeto significaba literalmente "estar sujeto" a los dictados de lo natural; "subjectum" a las leyes inmutables del cosmos. El cambio de actitud significó entronizar al experimento como interrogación reglada y, al mismo tiempo, dominadora frente a lo natural. La idea del "experimentum crucis", la respuesta definitiva sobre un asunto, equivalía a desatar de un golpe el nudo gordiano de un misterio. La naturaleza domeñada deja de ser natura naturans y pasa a ser natura naturata, domeñada y ordenada por la interrogación inteligente.

Tema persistente en la ciencia occidental fue la separación entre lo inanimado y lo animado. En el siglo XIX, experimentos clásicos como la síntesis de la urea (Wöhler, 1826) sugirieron que la distancia entre uno y otro mundo puede cruzarse. Como luego dirían Claude Bernard y los experimentalistas médicos, lo que separa lo animado de lo inanimado, lo orgánico de lo inorgánico, no es algo sustancial sino de arreglo, de estructura, de funciones. Toda la jerarquía introducida por Bichat desde la célula al tejido y luego al órgano supone que los constituyentes de la materia viva son los mismos que se encuentran en todo el universo, pero la Vida es una forma especial de ordenamiento con propia legitimidad; por ende, debe estudiarse con arreglo a una metódica que tome en cuenta las complejidades ascendentes de sus diversos constituyentes.

Aunque la historia de la fisiología muestra en el siglo XIX una polémica entre mecanicistas y vitalistas, esa ciencia se constituye en fundamento de las metáforas más ricas para abordar los problemas mayores de la humanidad. La biología y la medicina románticas del siglo XIX alemán usaron extensamente la metáfora para arribar a certidumbres. Fueron desplazadas por las ciencias positivas que, reconociendo la diferencia entre lo vivo y lo inanimado, insistieron no obstante en la comunidad de los métodos para abordar todas las cuestiones importantes. El positivismo desterró por un tiempo el pluralismo metódico que hoy rescatamos como una conquista de la posmodernidad y como un avance hacia la legitimidad de ciencias como las sociales, cuya realidad es mudable y no estática, como se presumió era la de las "leyes" inmutables del cosmos. 
En este panorama, el empleo del animal como fuente de informaciones ha tenido muchos significados. Por un lado, ha sido simple fuente de células y tejidos sin que su entidad de ser animado importara mucho. Por otro, ha sido modelo o esquema de lo que puede acontecer en el ser humano bajo condiciones similares. Y, también, ha sido objeto de estudio por sí mismo, como en la etología y otras ciencias del comportamiento. En muchos textos prevalece la idea instrumental del "reactivo biológico", en el sentido de objeto que reacciona.

No ha sido ajena a este desarrollo la creencia de que la especie humana representa el pináculo evolutivo y la culminación de la Creación. Es difícil separar la influencia de la mentalidad judeocristiana de los aportes de la teoría evolutiva, que en algún momento histórico pareció irreconciliable con los preceptos religiosos. La convicción de que Dios puso al Hombre (diríamos, la especie humana) para enseñorearse de todo lo creado puede hacer parecer legítimo usar y abusar de los animales para alimento, vestido y conocimiento. La sola presunción de que los seres humanos son una especie más, con orígenes especificables, pareció un insulto a esa profunda creencia. De modo que el empleo del animal en las ciencias es solamente una faceta, o aspecto, de la relación entre especies, que siempre será problema tanto técnico como moral.

Aunque la asociación entre el Centro Interdisciplinario de Estudios en Bioética (CIEB) de la Universidad de Chile y el Programa de Bioética de OPS/OMS se aboca especialmente a asuntos relacionados con la salud humana individual y colectiva y, por ende, centra su atención en estudios con sujetos humanos, es indispensable reflexionar sobre las actitudes hacia los animales y las creencias subyacentes, porque las fronteras no son nítidas y la reflexión bioética es más que una reflexión sobre moralidad humana. Este número de nuestra revista complementa el libro reciente "El animal como sujeto experimental. Aspectos técnicos y éticos", disponible en www.paho. org/bioetica. Con él deseamos situar la reflexión en un plano de interpretación, ojalá racional, de un auténtico dilema: cómo respetar la vida en todas sus formas y cómo ser fiel al espíritu de interrogación que funda la ciencia y es promesa de progreso, bienestar y paz cuando lo legitiman el consenso y la buena voluntad.

Este número de Acta Bioethica no pretende ser exhaustivo en el tema y se ofrece, como otros, como incitación al diálogo, constituyente nuclear de la empresa bioética. En él incluimos además aportes misceláneos remitidos a la revista y aprobados por los pares evaluadores. La novedad de este número es una nueva sección, llamada Colectánea, cuya finalidad y caracteres se explican en el debido lugar. 